\title{
POTENTIAL TOXIC CYANOBACTERIA IN THREE LAKES OF JAKARTA-BOGOR AREA, INDONESIA
}

\author{
Nining Betawati Prihantini*, Arya Widyawan, Ronny Rianto, Yuni Ariyani, \\ Wisnu Wardhana, Dian Hendrayanti \\ Department of Biology \\ Faculty of Mathematics and Natural Science, University of Indonesia \\ Depok 16424 Indonesia \\ "e-mail: nprihantini@hotmail.com
}

\begin{abstract}
The research was aimed to understand the composition and dominancy of aquatic microalgae, and to know the potential toxicity of Cyanobacteria occuring in three lakes of Jakarta-Bogor area. The study was done in 2006. The sampling sites were Lake Sunter 2 (North Jakarta), Lake Babakan (South Jakarta), and Lake Lido (Bogor). The water samples were taken using plankton-net ( $20 \mu \mathrm{m}$ mesh) with horizontal tow. The results showed that the number of microalgal genera in Sunter 2, Babakan, and Lido were different, i.e. 10 genera, 40 genera, and 14 genera, respectively. Cyanobacteria were dominant in Sunter $2(96 \%)$ and Babakan (90.01\%). The dominant Cyanobacteria in Sunter 2 was Planktothrix agardhii (53.48\%), whereas in Babakan was Chroococcus dispersus (68.52\%). The second abundant Cyanobacteria in Sunter 2 was Arthrospira (42.54\%). Planktothrix agardhii and Arthrospira are known to produce harmful toxin.
\end{abstract}

Keywords: Sunter 2, Babakan, Lido, Planktothrix, Arthrospira.

\section{INTRODUCTION}

Cyanobacteria or Cyanophyta is one of the microalgal divisions that often occurs abundantly in the fresh, brackish, or marine waters. It becomes a part of Harmful Algal Bloom (HAB) phenomenon. These microorganisms have been known to have wide range of habitat condition compared to other aquatic microalgae. This character causes Cyanobacteria to grow in extreme environmental condition. Usually optimal growth occurs if the water temperature is warm enough $\left(25-35^{\circ} \mathrm{C}\right)$, acquire enough light intensity, the water is alkaline $(\mathrm{pH} 7.5-9)$, and nutrient concentration increase during eutrophication (Nicholas, 1980).

Almost all members of Cyanobacteria can produce toxin and are usually called toxic Cyanobacteria, for examples, Microcystis, Anabaena, Planktothrix / Oscillatoria, Nostoc, Aphanizomenon, and Cylindrospermopsis (Carmichael, 1995). These toxins occur in the waters because dead microalgae release chemical substance (toxins) into the waters. Toxins can be hepatotoxic (microcystin and nodularin) and neurotoxic (anatoxin). Microcystin that can damage liver is produced by Microcystis aeruginosa, whereas anatoxin, which can damage the nervous system, is produced by Anabaena flos-aquea and Aphanizomenon flos-aquea (Carmichael, 1995; Hoek et al., 1995).

Cyanobacteria occur abundantly in several lakes and ponds in and around Jakarta. Bluishgreen scums cover many water surfaces which indicates that Cyanobacteria is blooming in the waters. In Depok (near Jakarta) for example, Cyanobacteria were dominated in Baru Pond in 1994 (Budiman, 1995), and Rawa Besar and Rawa Kalong Pond in 1998 (Junwinanto, 1998). A preliminary research in Lakes Sunter 2 and Sunter Barat showed that Plantothrix agardhii was dominant in 2003. This species also occurred in the ponds of University of Indonesia (Prihantini et al., 2006; Rianto et al., 2006).

Although Cyanobacteria seem to be dominant in several lakes and river, the abundance of the 
scum does not spread everywhere. The explorations on aquatic microalgae in three lakes of Jakarta-Bogor area were done to understand the composition and dominancy of aquatic microalgae, and to know the potential of toxic Cyanobacteria, in those three lakes.

\section{MATERIAL AND METHODS}

The samples were taken from Lake Babakan (South Jakarta) in August 2006, and from Lake Sunter 2 (North Jakarta) and Lake Lido (Bogor) in September 2006. All samples were collected between 10.00 am to $12.00 \mathrm{am}$ (Western Indonesia Time). Sampling site was decided with purposive sampling, and conducted at three stations, i.e. inlet, midlet, and outlet of the lakes. The water was sampled using plankton net with horizontal tow in triplicate. The samples were fixed with $6 \%$. Fresh samples were also taken in order to isolate the Cyanobacteria and to support identification.

Environmental parameters were measured at every station. The parameters were temperature, $\mathrm{pH}$, light intensity, transparency, DO, conductivity, $\mathrm{N}$ and $\mathrm{P}$ concentrations. $\mathrm{DO}$ values was measured using DO meter, whereas $\mathrm{N}$ and $\mathrm{P}$ concentrations were determined at laboratory following the methods described in Hutagalung et al. (1997).

Identification was done with Nikon SE light microscope with gradual magnification from (10x4), (10x10), (10x40), and (10x100). Identification references used were Edmonson (1959), Pentecost (1984), Geitler (1985), Santra (1993), and Whitton (2002). The density of microalgae $\mathrm{m}^{-3}$ (D) was estimated from the sub-samples and application of the formula, $\mathrm{D}=\mathrm{q} \times 1 / \mathrm{f} \times 1 / \mathrm{v}$
(Wickstead, 1965), where $q=$ cell counts, $f=$ fraction examined, and $\mathrm{v}=$ volume of water filtered $\left(\mathrm{m}^{3}\right)$. V was estimated by the formula, $\mathrm{v}=$ $\pi r^{2} \times$ t (Greenberg et al., 1992), where $r$ is plankton-net radius $(10 \mathrm{~cm})$, and $t$ is distance tow $(5 \mathrm{~m})$.

\section{RESULTS}

The results of environmental measurement in the three lakes were different. The data showed that water temperature in Lake Sunter 2 (28.5 to $32^{\circ} \mathrm{C}$ ) was warmer than other two lakes. The $\mathrm{pH}$ in Lake Sunter 2 was alkaline (8), and light intensity was more than 500,000 lux. Beside that, the dissolved oxygen and conductivity were higher than the other two lakes. Other environmental data can be seen at Table 1 .

The numbers of microalgae found in the three lakes are shown in Table 2. Ten genera were found in Lake Sunter 2, 40 genera in Lake Babakan, and 14 genera in Lido Lake.

The total numbers of genera identified easily were 45 comprising with Chromophyta (seven genera), Chlorophyta (22 genera), Cyanobacteria / Cyanophyta (14 genera), Dinophyta (one genus), and Euglenophyta (three genera).

The Cyanobacteria were found dominantly in Sunter 2 and Babakan (Fig. 1). Two genera were found blooming in Sunter 2 i.e. Planktothrix (53.48\%) and Arthrospira (42.54\%), whereas Choococcus dispersus was blooming in Babakan $(68.52 \%)$. Lido was not dominated by Cyanobacteria, but Chlamydomonas (Chlorophyta) was blooming in the lake $(70.15 \%)$.

Table 1. Environmental data of Lakes Sunter 2, Babakan, and Lido

\begin{tabular}{|c|c|c|c|c|c|c|c|c|c|}
\hline $\begin{array}{l}\text { Sampling } \\
\text { site }\end{array}$ & Stasiun & $\begin{array}{c}\text { Temp } \\
\left({ }^{\circ} \mathrm{C}\right)\end{array}$ & $\begin{array}{l}\text { Light Int. } \\
\quad \text { (lux) }\end{array}$ & $\begin{array}{c}\text { Transpa } \\
\text { rancy } \\
\text { (cm) }\end{array}$ & $\mathrm{pH}$ & DO & $\begin{array}{c}\text { Conduc } \\
\text { tivity ( } \mu \text { MHos) }\end{array}$ & $\begin{array}{l}\text { N cont. } \\
\text { (ppm) }\end{array}$ & $\begin{array}{l}\text { Pcont. } \\
\text { (ppm) }\end{array}$ \\
\hline \multirow{3}{*}{$\begin{array}{l}\text { Sunter } 2 \\
\text { Lake }\end{array}$} & inlet & 28.5 & $>500000$ & 14 & 8 & 7.4 & 1000 & \multirow[t]{3}{*}{11.81} & \multirow[t]{3}{*}{0.23} \\
\hline & outlet & 30.5 & $>500000$ & 15 & 8 & 13.9 & 1150 & & \\
\hline & centre & 32 & $>500000$ & 16 & 8 & 10.3 & 1200 & & \\
\hline \multirow{3}{*}{$\begin{array}{l}\text { Babakan } \\
\text { Lake }\end{array}$} & inlet & 27 & 163100 & 27 & 7 & 4.0 & 310 & \multirow[t]{3}{*}{12.75} & \multirow[t]{3}{*}{0.08} \\
\hline & outlet & 29 & 193700 & 37 & 7 & 4.7 & 250 & & \\
\hline & centre & 29 & $>500000$ & 29 & 7 & 8.4 & 250 & & \\
\hline \multirow[t]{3}{*}{ Lido Lake } & inlet & 27 & $>50000$ & 170 & 6 & 6.3 & 168 & \multirow[t]{3}{*}{21.4} & \multirow[t]{3}{*}{0.17} \\
\hline & outlet & 27 & $>50000$ & 207 & 6 & 7.3 & 170 & & \\
\hline & centre & 27 & $>50000$ & 27 & 6 & 4.1 & 171 & & \\
\hline
\end{tabular}


Table 2. Composition and density of plankton in the lakes of Sunter 2, Babakan and Lido

\begin{tabular}{|c|c|c|c|c|c|}
\hline \multirow{2}{*}{ No. } & \multirow{2}{*}{ Division } & \multirow{2}{*}{ Genus/Species } & \multicolumn{3}{|c|}{ Density (\%) } \\
\hline & & & Lake Sunter 2 & Lake Babakan & Lake Lido \\
\hline 1 & Chromophyta & Cyclotella & 0.00 & 0.79 & 0.00 \\
\hline 2 & Chromophyta & Cymbella & 0.00 & 0.00 & 0.10 \\
\hline 3 & Chromophyta & Melosira & 0.00 & 0.14 & 19.69 \\
\hline 4 & Chromophyta & Navicula & 0.00 & 0.25 & 0.00 \\
\hline 5 & Chromophyta & Nitzchia & 0.00 & 0.29 & 0.00 \\
\hline 6 & Chromophyta & Pinnularia & 0.00 & 0.03 & 0.10 \\
\hline 7 & Chromophyta & Pseudonitszchia sp. & 0.22 & 0.00 & 0.00 \\
\hline 8 & Chlorophyta & Actinastrum & 0.00 & 0.29 & 0.00 \\
\hline 9 & Chlorophyta & Ankyra & 0.00 & 0.00 & 0.10 \\
\hline 10 & Chlorophyta & Chlamydomonas & 0.00 & 0.63 & 70.15 \\
\hline 11 & Chlorophyta & Chlorella & 0.00 & 0.04 & 0.00 \\
\hline 12 & Chlorophyta & Closterium & 0.00 & 0.01 & 0.05 \\
\hline 13 & Chlorophyta & Coelastrum & 0.58 & 0.13 & 1.35 \\
\hline 14 & Chlorophyta & Coelosphaerium & 0.00 & 0.49 & 0.00 \\
\hline 15 & Chlorophyta & Crucigenia & 0.00 & 0.15 & 0.00 \\
\hline 16 & Chlorophyta & Crucigeniella & 0.00 & 0.19 & 0.00 \\
\hline 17 & Chlorophyta & Dictyosphaerium & 0.00 & 0.99 & 0.34 \\
\hline 18 & Chlorophyta & Golenkinia & 0.00 & 0.01 & 0.00 \\
\hline 19 & Chlorophyta & Kirchneriella & 0.00 & 0.04 & 0.00 \\
\hline 20 & Chlorophyta & Micractinium & 0.73 & 0.00 & 0.00 \\
\hline 21 & Chlorophyta & Monaraphidium & 0.00 & 0.16 & 0.00 \\
\hline 22 & Chlorophyta & Pandorina & 0.11 & 0.06 & 4.06 \\
\hline 23 & Chlorophyta & Pediastrum & 0.00 & 0.16 & 0.00 \\
\hline 24 & Chlorophyta & Scenedesmus & 0.02 & 1.83 & 0.00 \\
\hline 25 & Chlorophyta & Selenastrum & 0.00 & 0.03 & 0.00 \\
\hline 26 & Chlorophyta & Staurastrum & 0.00 & 0.07 & 0.00 \\
\hline 27 & Chlorophyta & Tetrastrum & 0.00 & 0.14 & 0.00 \\
\hline 28 & Cyanobacteria & Aphanothece & 0.00 & 0.08 & 0.00 \\
\hline 29 & Cyanobacteria & Arthrospira & 42.54 & 7.75 & 0.00 \\
\hline 30 & Cyanobacteria & Chroococcus & 0.00 & 1.23 & 0.00 \\
\hline 31 & Cyanobacteria & Chroococcus dispersus & 0.00 & 68.52 & 0.00 \\
\hline 32 & Cyanobacteria & Gloeocapsa sp. & 0.00 & 0.00 & 0.48 \\
\hline 33 & Cyanobacteria & Merismopedia & 0.00 & 2.75 & 0.00 \\
\hline 34 & Cyanobacteria & Microcystis aeruginosa & 0.00 & 2.89 & 0.68 \\
\hline 35 & Cyanobacteria & Microcystis sp. & 0.00 & 1.97 & 0.00 \\
\hline 36 & Cyanobacteria & Oscillatoria sp.1 & 0.00 & 0.38 & 0.29 \\
\hline 37 & Cyanobacteria & Oscillatoria sp.3 & 0.00 & 2.88 & 0.00 \\
\hline 38 & Cyanobacteria & Planktothrix agardhii & 53.48 & 0.25 & 0.00 \\
\hline 39 & Cyanobacteria & Romeria & 0.00 & 0.83 & 1.40 \\
\hline 40 & Cyanobacteria & Spirulina & 0.00 & 0.30 & 0.00 \\
\hline 41 & Cyanobacteria & Synechococcus & 0.00 & 0.18 & 0.00 \\
\hline 42 & Dinophyta & Peridinium & 0.00 & 0.07 & 0.00 \\
\hline 43 & Euglenophyta & Euglena & 2.29 & 0.90 & 0.00 \\
\hline 44 & Euglenophyta & Phacus & 0.03 & 0.07 & 0.00 \\
\hline 45 & Euglenophyta & Trachelomonas & 0.01 & 2.03 & 1.21 \\
\hline \multicolumn{3}{|c|}{ Total Genera } & 10 & 40 & 14 \\
\hline
\end{tabular}

\section{DISCUSSION}

Among the 45 genera found in the three lakes, 14 genera were belonging to the division Cyanobacteria. In Lake Babakan, 13 genera of
Cyanobacteria were common, whereas in Lake Lido were four genera, and in Lake Sunter 2 only two genera were found.

Even though only two genera of Cyanobacteria were easily found in Sunter 2, they were dominant. 


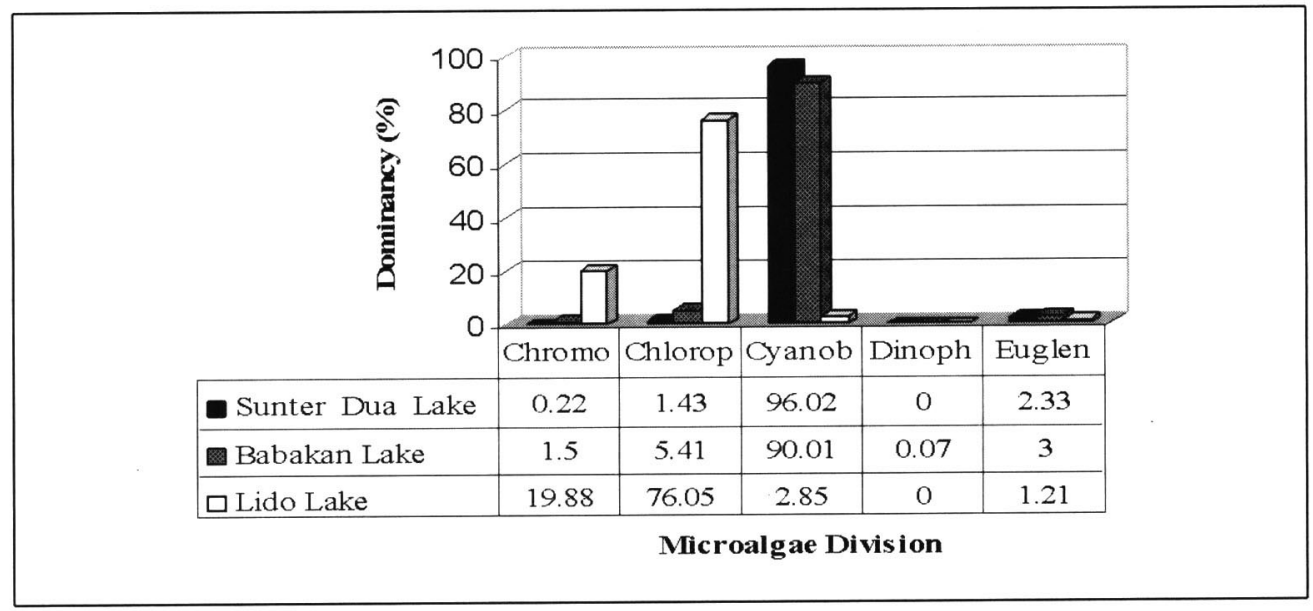

Figure 1. Microalgal dominancy in Lakes Sunter 2, Babakan, and Lido

The genus or species Planktothrix / Planktothrix agardhii posses the highest densities (53.48\%), whereas Arthrospira become the second majority $(42.54 \%)$. The abundant Cyanobacteria (Planktothrix and Arthrospira) in the Sunter 2 probably were caused by the water condition. Cyanobacteria have been known to have range of wide habitat condition if compared to others aquatic microalgae. The water condition of Sunter 2 support Cyanobacteria to grow abundantly, especially because of $\mathrm{pH} 8$, water temperature range from 28.5 to $32^{\circ} \mathrm{C}$, and light intensity more than 500,000 lux. The water $\mathrm{pH}$ can inhibit the distribution of Cyanobacteria (Sze, 1998). Generally, Cyanobacteria are uncommon in acidic $\mathrm{pH}$ waters, but tend to grow better in neutral and alkaline $\mathrm{pH}$, and enough light intensity (Nicholas, 1980). More over, polluted lakes in tropical country illuminated by high sun light intensity, and high temperature can supply optimal condition for the growth of Cyanobacteria (Kumar and Singh, 1979). These optimal conditions will be conducive if there is an increasing $\mathrm{P}$ and $\mathrm{N}$ concentration in the water (Odum, 1993). Finally, seasons are also able to influence the occurrence of microalgae blooms (Willen and Willen, 1978).

Both genera mentioned above are known to produce toxin, which is harmful to the lake. The toxins produced includes anatoxins (neurotoxins), microcystin (hepatoxins), and saxitoxin (neurotoxins) (Carmichael, 1995). Recent studies have shown that Planktothrix produces potent toxins in addition to the well-characterised microcystin (Blom et al., 2003; Tonk et al., 2005;
Lance et al., 2006). Beside that, Arthrospira is also potentially toxic Cyanobacteria. Like Planktothrix, most members of this genus also can produce hepatotoxins and neurotoxins (Carmichael, 1995; Stewart et al., 2006).

A member of Cyanobacteria $(90.01 \%)$ also dominated in Babakan, which Chroococcus dispersus contributed about $68.52 \%$. Some potential toxic Cyanobacteria found in Babakan were Arthrospira (7.75\%), Microcystis aeruginosa (2.89\%), Microcystis sp. (1.97\%), and Planktothrix agardhii $(0.25 \%)$. Cyanobacteria was not only the dominant genera, but also the highest genera number compared to those in Sunter 2 (10 genera) and Lido (14 genera). This condition maybe occur because the domination of Chroococcus does not influence the growth of other genera in the lake.

The water condition of Babakan was a little bit different from Sunter 2. Water temperature, $\mathrm{pH}$, and light intensity were from 27 to $29^{\circ} \mathrm{C}, 7$, and 163,100 to more than 500,000 lux in range, respectively. This condition is optimal for Cyanobacteria growth, and Chroococcus dispersus was blooming at that time. The Lake Babakan is relatively not polluted because it is a tourism area and treated with a good management.

Lido has different condition from the other two lakes, especially for water temperature and $\mathrm{pH}$. Water temperature was cooler than in Sunter 2 and Babakan. The $\mathrm{pH}$ was also more acidic than the other two lakes. These conditions seem to be favourable for Chlamydomonas (division Chlorophyta) which contributed up to $70.15 \%$. 
Eventhough enough light intensity (more than 500,000 lux), Cyanobacteria were not common to be found in Lido. Only four genera were found, i.e. Gloeocapsa sp. $(0.48 \%)$, Microcystis aeruginosa (0.68\%), Oscillatoria sp $1(0.29 \%)$, and Romeria $(1.40 \%)$. Isolation of all these Cyanobacteria have been done for culturing in order to study the toxicity of those Cyanobacteria.

\section{CONCLUSION}

The composition of aquatic microalgae comprise of ten genera in Sunter 2, 40 genera in Babakan, and 14 genera in Lido. These genera belong to five division of microalgae i.e. Chromophyta (class Bacillariophyceae), Chlorophyta, Cyanobacteria, Dinophyta, and Euglenophyta. The dominant genus/species was Planktothrix agardhii (Cyanobacteria) in Sunter 2, Chroococcus dispersus (Cyanobacteria) in Babakan, and Chlamydomonas (Chlorophyta) in Lido. Some potential toxic Cyanobacteria were found in these three lakes i.e. Planktothrix agardhii and Arthrospira in Sunter 2, Planktothrix agardhii, Arthrospira, Microcystis aeruginosa and Microcystis sp1 in Babakan, and Microcystis aeruginosa in Lido

Acknowledgements. This work is partly supported by a grant from University of Indonesia for fiscal year 2006 (Riset Unggulan Universitas Indonesia 2006). I would like to express my gratitude to Prof. Dr. Yasuwo Fukuyo (The University of Tokyo, Japan) for every assistance and encouragement.

\section{REFERENCES}

Blom, J.F., B. Bojan, D. Bischoff, G. Nicholso, G. Jung, R. Sfissmuth, and F. Juttner. 2003. Oscillapeptin a new grazer toxin of the freshwater cyanobacterium Planktonic rubescens. J. Nat.Prod., 66: 431-434.

Budiman, F.R. 1995. Produkstivitas primer dan komunitas fitoplankton situ baru dan situ rawa besar, Depok, Jawa barat. Skripsi Jurusan Biologi FMIPA UI 1995: viii + 66p.

Carmichael, W.W. 1995. Cyanobacterial toxins. In: Hallegraeff, G.M., D.M. Anderson. \& A.D. Cembella (eds). 1995. Manual on harmful marine microalgae. Unesco, Paris: 163-175p.

Edmondson, W.T. 1959. Freshwater biology. 2nd ed. John Wiley and Sons Inc., New York: 1203p.
Greenberg, A.E., L.S. Clesceri and A.D. Eaton. 1992. Standard methods for the examination of water and wastewater. 18th ed. American Public Health Association, Washington: xxxi + 10-137p.

Geitler, L. 1985. Cyanophyceae. Koeltz Scientific Books, Koenigstein: vi $+1196 \mathrm{p}$

Hoek, C. Van den, D.G. Mann and H.M. Jahns. 1995. Algae: An introduction to phycology. Cambridge University Press, Melbourne: xi $+623 \mathrm{p}$.

Hutagalung, H.P., D. Setiapermana and S. H. Riyono (eds.). 1997. Metode analisis air laut, sedimen dan biota. Buku 2. Pusat Penelitian dan Pengembangan Oseanologi, Lembaga Ilmu Pengetahuan Indonesia, Jakarta: $\mathrm{x}+182 \mathrm{p}$.

Junwinanto. 1998. Studi perbandingan struktur komunitas fitoplankton di situ rawa besar dan situ rawa kalong kabupaten Bogor, Jawabarat. Skripsi Jurusan Biologi FMIPA UI 1998: ix + 78p.

Kumar, H.D. and F.N. Singh. 1979. A textbook on algae. The Macmillan Press, LTD, Tokyo: vii +216p.

Lance, E., L. Brient, M. Bormans, and C. Gerard. 2006. Interactions between cyanobacteria and gastropods I. Ingestion of toxic Plantothrix agardhii by Lymnaea stagnalis and the kinetics of microcystin bioaccumulation and detoxification. Aquat. Toxicol., 79: 140-148.

Nicholas, D.J.D. 1980. Mineral nutrients requirements of utilization by algal flora of freshwater lake. Technical Paper No. 50. Research project no 74/72, Australian Government Publishing Service, Canberra: viii $+51 \mathrm{p}$.

Odum, E.P. 1993. Dasar-dasar ekologi. Ed ke-3. Terjemahan. Dari Fundamentals of Ecology, oleh Samingan, Tjahjono. Gadjah Mada Uiversity Press, Yogyakarta: xv +697p.

Pentecost, A. 1984. Introduction to fresh water algae. Richmond Publishing Co. Ltd., England: vii +247p.

Prihantini, N.B., W. Wardhana, A. Widyawan, and R. Rianto. 2006. Cyanobacteria dari beberapa situ dan sungai di kawasan Jakarta dan Depok, Indonesia. Prosiding Seminar Nasional Limnologi 2006, Puslit Limnologi, LIPI, Jakarta: 210-221.

Rianto, R., A. Widyawan, N.B. Prihantini, W. Wardhana, and D. Hendrayanti. 2006. Aquatic microalgae in Agathis and Kenanga Ponds of University of Indonesia, Depok: Focus on Cyanobacteria division. Proc. of International Conference on Mathematics and Natural Sciences (ICMNS) Bandung, 2006: 318-321.

Santra, S.C. 1993. Biology of Rice-fields blue-green algae. Daya Publishing House, New Delhi: vii + 229 . 
Sze, P. 1998. A biology of the algae. 3rd ed.WCB. McGraw-Hill, Boston: viii + 278p.

Stewart, Ian, P.M Webb, P.J Schluter and G.R Shaw. 2006. Recreational and occupational field exposure to freshwater cyanobacteria - a review of anecdotal and case reports, epidemiological studies and the challenges for epidemiologic assessment. BioMed Central Ltd., 5: 6.

Tonk L., P.M. Visser, G. Christiansen, E. Dittmann, E.O.F.M. Snelder, C. Wiedner, L.R. Mur, and J. Huisman. 2005. The microcystin composition of the cyanobacterium Planktothrix agardhii changes toward a more toxic variant with increasing light intensity. Appl. Environ. Microbial., 71: 51775181.
Whitton, B.A. 2002. Phylum Cyanophyta (Cyanobacteria). In: Jhon, D.M. B.A. Whitton \& A.J. Brook (eds). The freshwater alga flora of The British Isles: an identification guide to freshwater and terrestrial algae. Cambridge University Press, Cambridge: p.25-122.

Wickstead, .J.H. 1965. An introduction to the study of tropical plankton. Hutchinson Tropical Monographs, London: 160p.

Willen, E. and T. Willen. 1978. About freshwater phytoplankton. In: Phytoplankton manual. UNESCO, Paris: 297-301. 